\title{
A Bibliometric analysis of folate receptor research
}

\author{
Cari A. Didion ${ }^{*+}$ (D) and Walter A. Henne ${ }^{\dagger}$
}

\begin{abstract}
Background: The objective of this study was to conduct a bibliometric analysis of the entire field of folate receptor research. Folate receptor is expressed on a wide variety of cancers and certain immune cells.

Methods: A Web of Science search was performed on folate receptor or folate binding protein (1969-to June 28, 2019). The following information was examined: publications per year, overall citations, top 10 authors, top 10 institutions, top 10 cited articles, top 10 countries, co-author collaborations and key areas of research.

Results: In total, 3248 documents for folate receptor or folate binding protein were retrieved for the study years outlined in the methods section search query. The range was 1 per year in 1969 to 264 for the last full year studied (2018). A total of 123,720 citations for the 3248 documents retrieved represented a mean citation rate per article of 38.09 and range of 1667 citations (range 0 to 1667). Researchers in 71 countries authored publications analyzed in this study. The US was the leader in publications and had the highest ranking institution. The top 10 articles have been cited 7270 times during the time frame of this study. The top cited article had an average citation rate of 110 citations per year. Network maps revealed considerable co-authorship among several of the top 10 authors.
\end{abstract}

Conclusion: Our study presents several important insights into the features and impact of folate receptor research. To our knowledge, this is the first bibliometric analysis of folate receptor.

Keywords: Folate receptor, Folate binding protein, Cancer, Oncology, Macrophage, Imaging, Bibliometrics, Scientometrics, Librarianship-health sciences

\section{Background}

As a vital nutrient for normal cell metabolism, folate uptake in the cell occurs via a low-affinity $\left(K_{d} \sim 1-5 \mu \mathrm{M}\right)$ transport protein termed the reduced folate carrier [1] and a high-affinity $\left(\mathrm{K}_{\mathrm{d}} \sim 100 \mathrm{pM}\right)$ cell surface receptor termed the folate receptor (FR) or folate binding protein (FBP) [1-6]. Notably, FR is over-expressed at significant levels in cancer cells and immune cells (e.g., macrophages) where it mediates uptake of folate by receptormediated endocytosis [2, 7-12]. Although folate uptake occurs via the reduced folate carrier in virtually all cells

\footnotetext{
* Correspondence: cdidion@govst.edu
${ }^{+}$Both authors contributed equally to this work.

* Correspondence: cdidion@govst.edu
${ }^{\dagger}$ Both authors contributed equally to this work.

Governors State University, 1 University Parkway, University Park, IL 60484, USA
}

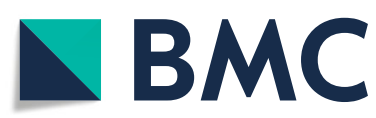

(c) The Author(s). 2020, corrected publication 2021. Open Access This article is licensed under a Creative Commons Attribution 4.0 International License, which permits use, sharing, adaptation, distribution and reproduction in any medium or format, as long as you give appropriate credit to the original author(s) and the source, provide a link to the Creative Commons licence, and indicate if changes were made. The images or other third party material in this article are included in the article's Creative Commons licence, unless indicated otherwise in a credit line to the material. If material is not included in the article's Creative Commons licence and your intended use is not permitted by statutory regulation or exceeds the permitted use, you will need to obtain permission directly from the copyright holder. To view a copy of this licence, visit http://creativecommons.org/ licenses/by/4.0/. The Creative Commons Public Domain Dedication waiver (http://creativecommons.org/publicdomain/zero/1. 0/) applies to the data made available in this article, unless otherwise stated in a credit line to the data. by means of the high affinity folate receptor [7-13].

The folate receptor exists as a family of proteins with three primary forms: FR- $\alpha$ (folate receptor 1 ) [14], FR- $\beta$ (folate receptor 2) [15], and FR- $\gamma$ (folate receptor 3) [16], and folate receptor delta (folate receptor 4) [17]. These folate receptor homologues are related by $\sim 70 \%$ amino acid sequence identity [5]. FR- $\alpha$ and FR- $\beta$ are attached to cell surfaces by a glycosylphosphatidylinositol (GPI) anchor, while the rarely expressed FR- $\gamma$ is hypothesized to be secreted due to lack of a signal for GPI modification [16]. Folate receptor delta does not bind folate and functions at the initial step of oocyte fertilization [18]. In general, FR- $\alpha$ is upregulated in malignant tissues of epithelial origin such as ovarian carcinoma [19-21] while FR- $\beta$ is overexpressed in certain subsets of macrophages [19]. 
This prevalence of FR over-expression in numerous neoplasms and macrophage associated diseases, has led to expansive growth in the use of the cognate folate moiety (as well as anti-FR antibodies) to selectively deliver both diagnostic and therapeutic agents. For example, folate has been conjugated to i) protein toxins $[13,22,23]$, ii) low molecular weight chemotherapeutic agents [11, 24, 25], iii) MRI contrast agents [26], iv) genes [27-32], v) viral vectors [33, 34], vi) antisense oligonucleotides [35-38], vii) ribozymes [39, 40], viii) radioimaging agents $[10,41-45]$, ix) liposomes with entrapped drugs [32, 46$48], x)$ neutron activation complexes [49, 50], xi) immunotherapeutic agents [51-56], enzyme constructs for prodrug therapy [57], nanoparticles [58], drug-linked polymers [59-61], micelles [62], and optical imaging agents $[63,64]$. Significantly, the above folate conjugates neither bind to nor transit through the reduced folate carrier: therefore, they exhibit no affinity for most normal cells [65]. Several promising agents have progressed from phase I through phase III clinical trials and the first diagnostic agents could reach the market in the next few years [66].

According to Andres [67], the term "bibliometrics" was first coined in 1969 and described as a means to apply a mathematical and statistical approach to the study of scientific literature. The term is synonymous with "scientometrics." However, for the purposes of this study we will use the term bibliometrics. As Kotepui, et al. [68], describe, bibliometric studies are used to obtain a research assessment rich with data that support a specific research interest. The data can be used to present a rich visualization about research undertakings the world round. Trends within a particular field are highlighted through descriptive analysis. Productivity can be demonstrated through the number of articles published, an author count, and by institutions or countries of origin among a myriad of other factors. Given the expansive rise in folate receptor related reports over the past several decades, we sought to analyze the entire field of FR literature. To our knowledge, this is the first bibliometric analysis of folate receptor.

\section{Methods}

For this bibliometric study the search of the available literature was conducted using the online index Web of Science by Clarivate Analytics. The Web of Science Core Collection provides regional citation indexes, patent data, specialized subject indexes, and an index of research data sets from within over 33,000 journals [69]. Using the Web of Science Core Collection, limiting for "articles," four searches were conducted as follows: "folate receptor" or "folate binding protein;" "folate receptor" or "folate binding protein" and "cancer" or "neoplasm;" "folate receptor" or "folate binding protein" and "inflammation" or "macrophage;" and "folate receptor" or "folate binding protein" and "imaging" or "diagnostics." An Excel spreadsheet was used to collect the following data for each of the four searches: total journal article search results, publication years (range), first known publication, year of publication, top ten countries/regions, top ten organizations, top ten authors, top ten citations, total citations and citations per year. Graphs for these data were performed using GraphPad Prism. VOSviewer version 1.6.11 software [70] was used to create the author co-authorship bibliometric network map (type of analysis $=$ co-authorship, units of analysis $=$ authors, counting method $=$ full counting, minimum number of documents of an author $=10$ ). Bibliometric key topic maps were constructed using VOSviewer version 1.6.11 [70] for both cancer and imaging search schemes (type of analysis = density visualization, item density, minimum number of occurrences $=50$ for cancer and 25 for imaging). Based on the number of articles retrieved, we focused primarily on the first search term "folate receptor" or "folate binding protein" leaving more specific analyses for future work of the rich subfields.

\section{Results}

\section{Literature retrieved for Folate receptor articles}

A total of 3248 documents for folate receptor or folate binding protein were retrieved for the study years outlined in the methods section search query (1969-to June 28, 2019). In this study only research articles in English were used for further analysis since English was the dominant language (99.4\%) identified. Review articles, conference proceedings, book chapters, etc., were excluded from the search criteria to avoid citation bias and potential duplication of work. A summary of document types found in the search are presented in Table 1.

Table 1 Types of retrieved documents for folate receptor research

\begin{tabular}{llll}
\hline Rank & Type of Documents & Frequency $\mathbf{N = 4 4 5 3}$ & Percentage \\
\hline 1 & Article & 3289 & $73.86 \%$ \\
2 & Meeting Abstract & 465 & $10.44 \%$ \\
3 & Review & 426 & $9.57 \%$ \\
4 & Proceeding Paper & 129 & $2.90 \%$ \\
5 & Book Chapter & 89 & $2.00 \%$ \\
6 & Editorial Material & 32 & $0.72 \%$ \\
7 & Correction & 11 & $0.25 \%$ \\
8 & Letter & 7 & $0.16 \%$ \\
9 & News Item & 5 & $0.11 \%$ \\
\hline
\end{tabular}




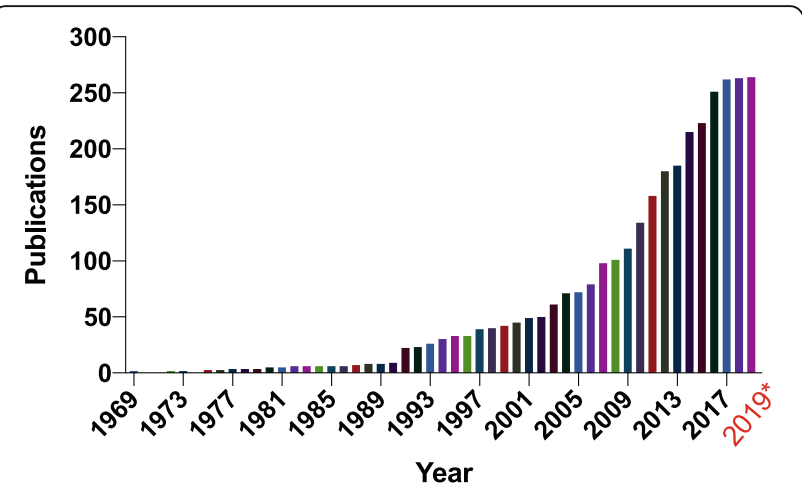

Fig. 1 Total number of folate receptor publications per year since 1969-present. *Note: partial year

\section{Publication and citation growth for Folate receptor articles}

There was a dramatic increase in the number of folate receptor works during the study period (Fig. 1). The range was 1 per year in 1969 to 264 for the last full year studied (2018). The highest productivity to date (263 publications) was in 2018: however, the number of articles generated per year appears may have started reaching a plateau in 2015. A total of 123,720 citations for the 3248 documents retrieved represented a mean citation rate per article of 38.09 and range of 1667 citations (range 0 to 1667).

\section{Publications by country for Folate receptor articles}

Researchers in 71 countries authored publications analyzed in this study. The top 10 countries accounted for 96.7\% (3140 articles) of the total publications (Fig. 2). The United States had the highest number of publications at $1314(40.5 \%)$ followed by China (25.1\%) at 815 and India at $174(5.4 \%)$ rounding out the top 3 counties by output. The publication productivity among the top

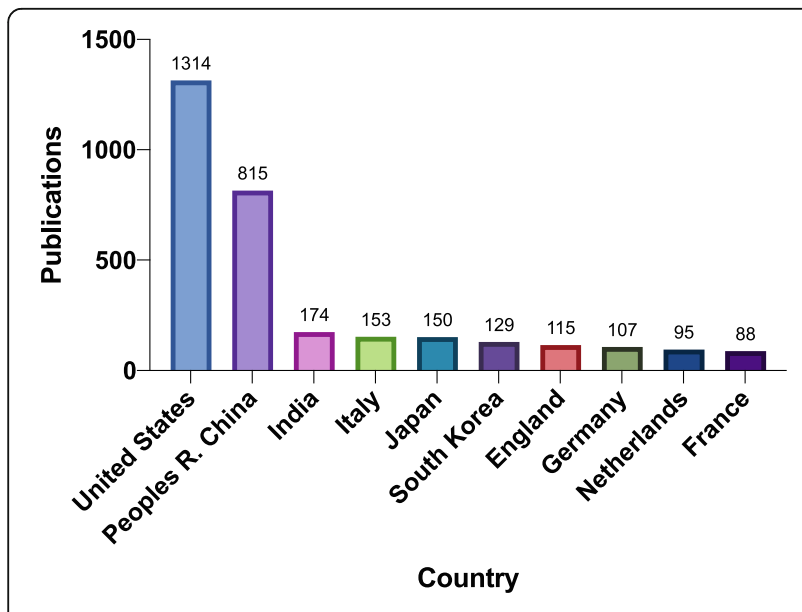

Fig. 2 Publications for the top 10 countries in folate receptor research
10 countries differed by as much as a factor of 14.9 (1st country versus the 10 th country by rank).

\section{Publications by institutions for Folate receptor articles}

The total number of unique institutions represented in this study was 2351. The top 10 institutions accounted for $24.1 \%$ (754 articles) of the total number of publications (Fig. 3). Purdue University had the highest number of publications at $170(5.2 \%)$ followed by the University of Texas System at $104(3.2 \%)$ and the National Institutes of Health $(\mathrm{NIH})$ at $75(2.3 \%)$ to round out the top 3 counties by output. Of note, a privately held company was in 5 th position at 70 research articles. The publication productivity among the top 10 institutions differed by as much as a factor of 3.5 (1st institution versus the 10th institution by rank).

\section{Publications by authors for Folate receptor articles}

The top 10 authors accounted for $18.1 \%$ (589) of the total number of research articles (Fig. 4). Low, P.S., had the highest number of publications at 139 (4.3\%) followed by Holm, J. at 60 (1.8\%) and Hansen, S.I., Lee, R.J., and Leamon, C.P tied at $59(1.8 \%)$ by output. The publication productivity among the top 10 authors differed by as much as a factor of 3.6 and was consistent with institution affiliation data (1st author versus the 10th author by rank).

\section{Top 10 citations for Folate receptor articles}

The top 10 research articles by total citations are listed in Table 2 [71] (Table follows the format established by Viana, et al). Also listed in 2 are citations per year (WoS does not provide standard deviation in their analytics for citations per year thus these values were calculated in Excel). These 10 articles have been cited 7270 times during the time frame of this study. The top cited article had a mean citation rate of 110 citations per year among the top 10 (Standard deviation). Mean citation rates differed by as much as a factor of 2. (1st paper versus the 10th paper by rank). Topics ranged from imaging (top 2 cited articles) to basic research articles regarding the

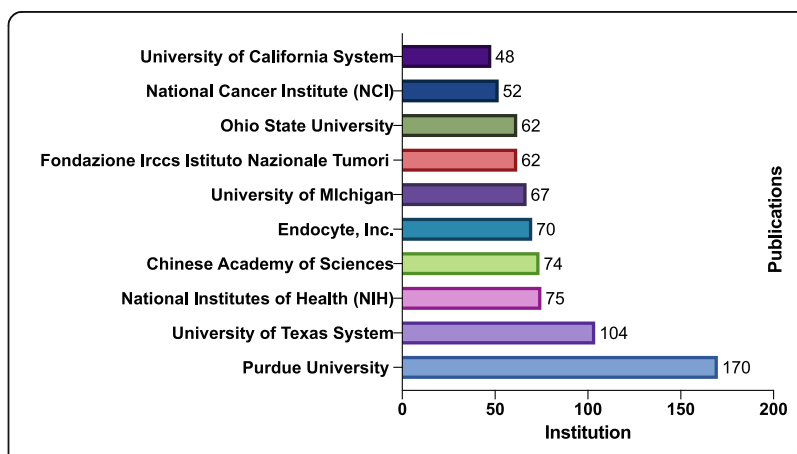

Fig. 3 Publications for folate receptor research at the top 10 institutions 


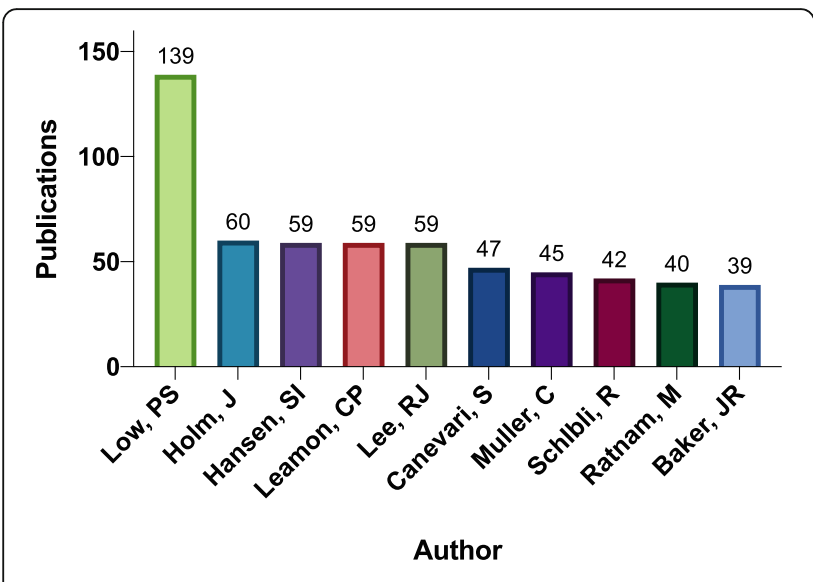

Fig. 4 Publications for the top 10 authors in folate receptor research

distribution of folate receptor to therapies and other diagnostic assays. In fact, imaging and therapies were featured in 5 of the top 10 cited articles.

\section{Folate receptor articles related to Cancer, macrophages and imaging}

Since folate receptor is a well-known target for cancer therapies, modalities associated with cells of the immune system (macrophages) and imaging agents, a refined search (see methods section) was conducted. Search queries involving cancer, macrophage and imaging agents revealed 2085 articles (64.2\%), 128 articles (3.9\%) and 752 articles (23.2\%), respectively, for each topical area. See Fig. 5. Bibliometric item intensity maps were constructed using VOSviewer version 1.6.11 [70] for both cancer and imaging (see Figs. 6 and 7).

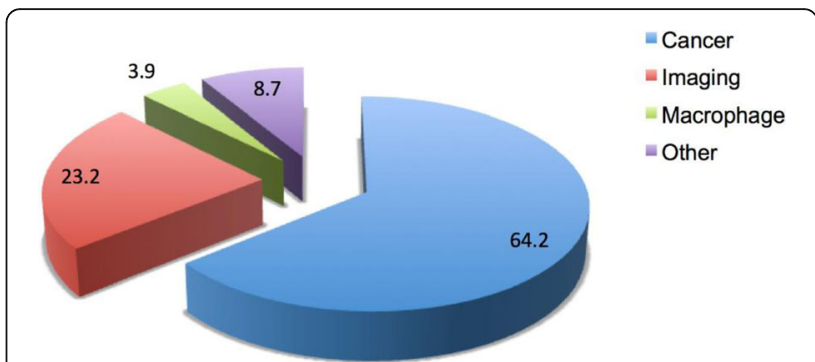

Fig. 5 Percentage of folate receptor articles associated with cancer, macrophage and imaging keywords

\section{Co-author Bibliometric network}

A co-authorship bibliometric network map was constructed using VOSviewer version 1.6.11 [70]. Major coauthorship researcher nodes included: Low, P.S., Leamon, C, Mueller, C and Lee, R.J. and Baker, JR. See Fig. 8.

\section{Discussion}

Folate receptor research publications increased considerably after the seminal work of Low and Leamon, which demonstrated uptake of conjugates via the folate receptor in receptor positive cancer cell lines [2]. The number of articles increased from 22 in 1991 to 263 in 2018 (the last full year studied). Although bibliometric studies of protein receptor ligands are limited, for comparison, a recent 25 year analysis of Sigma-1 receptor [72] yielded 1102 papers with 29,646 citations versus 3248 and 123,720 for folate receptor research. While the study of Sigma-1 receptor shows that article growth was not constant over time with large periods of stagnation, folate receptor research has experienced dramatic growth over roughly the same time frame with no periods of stagnation.

Table 2 Top 10 referenced publications by articles in the field of folate receptor or folate binding protein

\begin{tabular}{|c|c|c|c|c|}
\hline Author & Title & Year & $\begin{array}{l}\text { Total } \\
\text { Citations }\end{array}$ & $\begin{array}{l}\text { Citation } \\
\text { Rate Index }\end{array}$ \\
\hline Kam et al. & $\begin{array}{l}\text { Carbon nanotubes as multifunctional biological transporters and near-infrared agents for selective } \\
\text { cancer cell destruction }\end{array}$ & 2005 & 1667 & 119 \\
\hline Liong et al. & Multifunctional inorganic nanoparticles for imaging, targeting, and drug delivery & 2008 & 1309 & 119 \\
\hline Varma et al. & GPI-anchored proteins are organized in submicron domains at the cell surface & 1998 & 921 & 44 \\
\hline Weitman et al. & Distribution of the folate receptor GP38 in normal and malignant-cell lines and tissues & 1992 & 893 & 33 \\
\hline van Dam et al. & $\begin{array}{l}\text { Intraoperative tumor-specific fluorescence imaging in ovarian cancer by folate receptor-alpha tar- } \\
\text { geting: first in-human results }\end{array}$ & 2011 & 822 & 103 \\
\hline Ross et al. & $\begin{array}{l}\text { Differential regulation of folate receptor isoforms in normal and malignant-tissues in-vivo and in } \\
\text { established cell-lines - physiological and clinical implications }\end{array}$ & 1994 & 754 & 30 \\
\hline Parker et al. & $\begin{array}{l}\text { Folate receptor expression in carcinomas and normal tissues determined by a quantitative } \\
\text { radioligand binding assay }\end{array}$ & 2005 & 725 & 52 \\
\hline $\begin{array}{l}\text { Kukowska- } \\
\text { Latallo et al. }\end{array}$ & $\begin{array}{l}\text { Nanoparticle targeting of anticancer drug improves therapeutic response in animal model of } \\
\text { human epithelial cancer }\end{array}$ & 2005 & 657 & 47 \\
\hline Smart et al. & A detergent-free method for purifying caveolae membrane from tissue-culture cells & 1995 & 648 & 27 \\
\hline Kershaw et al. & A phase I study on adoptive immunotherapy using gene-modified $T$ cells for ovarian cancer & 2006 & 593 & 46 \\
\hline
\end{tabular}

${ }^{\mathrm{a} C i t a t i o n}$ Rate Index mean $=62$, standard deviation $=34.89$ 


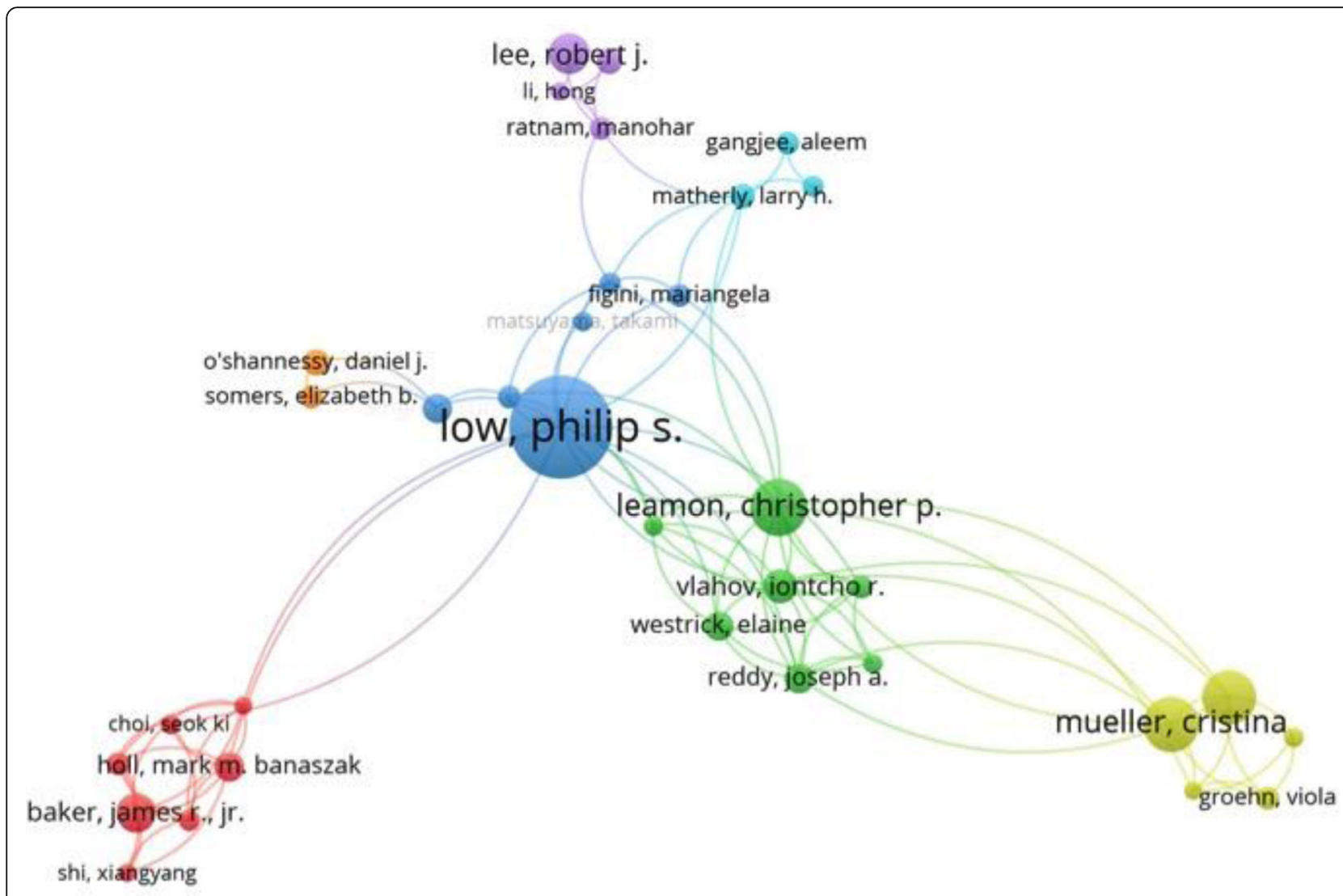

Fig. 6 Co-authorship network map of publications in the field of folate receptor or folate binding protein research

The large co-authorship nodes in the network map mirror several of the top 10 ten authors with Low occupying the central region, which is not surprising based on the historical progression of the field. Other prominent nodes included Mueller, Lee, Baker and Leamon. Given that folate receptor expression was found to be increased on cancer versus normal tissues, this feature provided a potential pathway for production of both therapeutic and diagnostic imaging agents. In fact, imaging in this early study played a key part in elucidation of folate mediated uptake of attached cargos [2]. Clinically, populations that will benefit from such targeted therapies need to be identified for treatment. This has been underscored by FDA guidance on the use of companion diagnostic for targeted therapies [73]. In addition to folate based MRI, CT, SPECT, PET and NIR imaging modalities [74], folate targeted agents are currently being explored for image-guided surgery for dubulkment of ovarian cancer tissue [75]. In our analysis, a folate guided surgery publication was the 5th most cited.

Moreover, our study detected an appreciable number of review articles (426 total) in addition to primary research articles that could be analyzed in future studies. A recent report by Blumel and Shniederman, based on inputs from the Conference of the International Society of Informetrics [76], proposes a broad agenda for the study of review articles. However, including such sizable numbers review articles within the framework of our current analyses would have been problematic. For instance, Ho [77] illustrates that review papers introduce bias in citation based analysis and that scholars must consider the purpose of the study and treat review papers distinctly to avoid this bias. Similar concerns have been earlier noted by Knottnerus [78]. There are also divergent definitions of what constitutes a review article including issues pointed out with WoS versus other databases noted by Ketcham [79].

The United States was the top article producing country followed by China and India. This is consistent with the output of Low (Purdue), Leamon (Endocyte), Lee (The Ohio State University), and the company Endoycte based in Purdue Research Park. There was a wide variation of publication productivity among the top 10 countries (differing by as much as a factor of 14.9 from the 1st country versus the 10th country by rank). Large state and federal (universities and institutes) and systems made up a large share of the top 10 institutions (e.g., Purdue, University of Texas, Chinese Academy of Sciences and $\mathrm{NIH}$ ) with the notable exception of the private company Endocyte. 


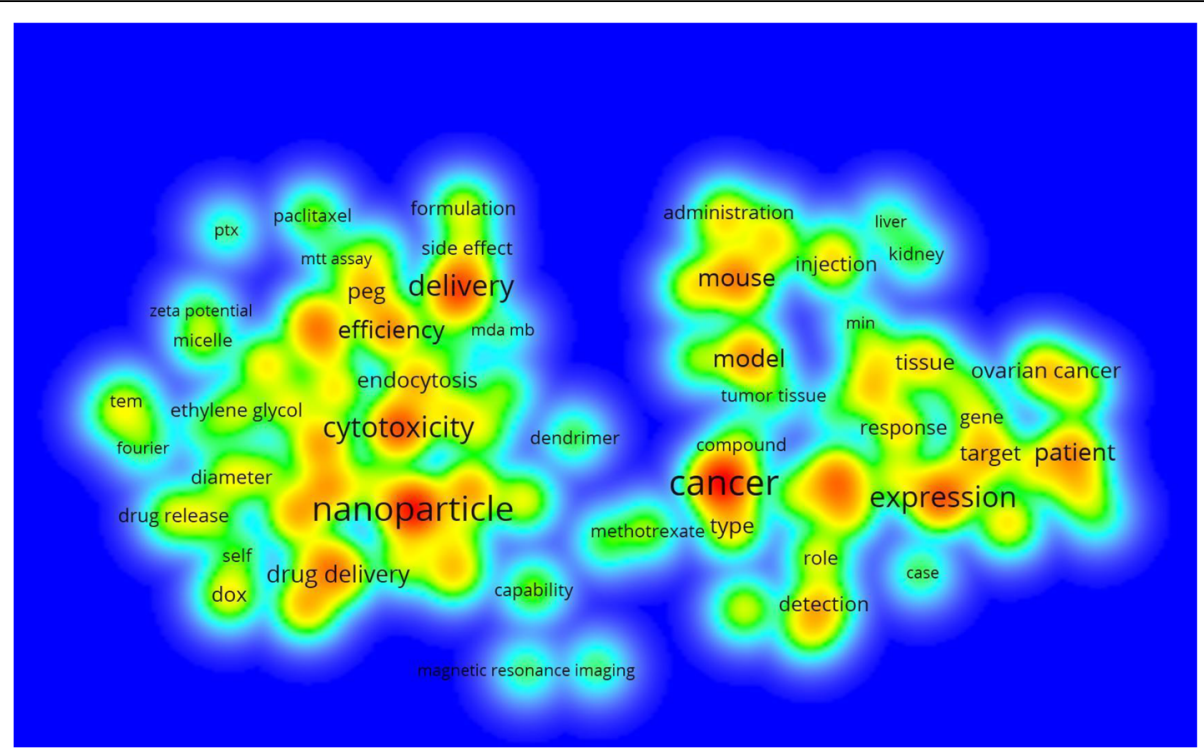

Fig. 7 Term density map of folate receptor research in imaging

The top 10 cited articles revealed a high proportion of therapeutic and imaging related studies. Specifically, several works outline the use of folate-guided nanomaterials agents for detection and treatment of folate receptor positive cancers. Folate is easily conjugated to various nanomaterials and several high receptor expressing cancer cell lines exist for testing these nanoconjugates [72]. The field of nanomedicine, in general, also experienced rapid citation growth during this time frame [80]. An analysis of citation rates per time, Table 2, revealed that the top two citations by Kam et al., and Liong et al., were tied with 119 citations per number of years since publication. Van Dam et al., while in the fifth position, has an average citation rate of 103 . Assessing the citation rate over time adds another layer of depth to the study of citations. Van der Pol et al. found a positive correlation between the quality and completeness of studies that adjusted for citation rates [81]. Hutchins et al. take it a step further and utilize a relative citation ratio whereby citation rates are divided by an expected citation rate that is a derivation from other articles in the same field within a peer comparison group [82]. This concept while not employed in this study, can be explored for further applications within the rich subfields of folate research.

Cancer was a key word associated with the majority of papers, followed by imaging and macrophages. Item density analyses of folate receptor subset areas yielded key topics including: nanoparticle, cytotoxicity, delivery, efficiency, expression, ovarian cancer, and fluorescence imaging, These areas were heavily represented in the top cited articles, especially articles associated with nanotechnology as previously outlined.
In fact, the top two cited articles in folate receptor research were in nanotechnology. This information could be used to help guide further analyses in this area of research.

This study has limitations that are related to the exclusive use of Web of Science. As Zyoud et al., cites English is the indisputable language of science, but this in itself is a limitation for bibliometric studies as databases omit publications written in other languages [83]. Web of Science was chosen for this study because, as Chen states, its records are standardized and more consistent than competitors [84]. The authors acknowledge that different databases will return different items. However, as Mansoori noted, Web of Science offered better tools to refine and analyze searches than Scopus [85].

\section{Conclusions}

Folate receptor research has led to the development of promising drug, imaging and other diagnostic schemes as well has had a profound impact on our understanding of receptor mediated cellular pathways. In this study, Web of Science was used to assess the global scientific production ranging from 1969-to June 28, 2019. Results illustrated a substantial increase in the cumulative volume of papers (264 per year for the last year studied). The US held the top metrics in publications, institutions and author output. The top 10 cited articles had an appreciable number of imaging and therapeutic applications, including nanotechnology. Given the different subareas of this dataset (e.g. imaging), there exists a rich source of data for further studies. Through bibliometric analysis, it should be possible to elucidate further interesting trends in these areas. 


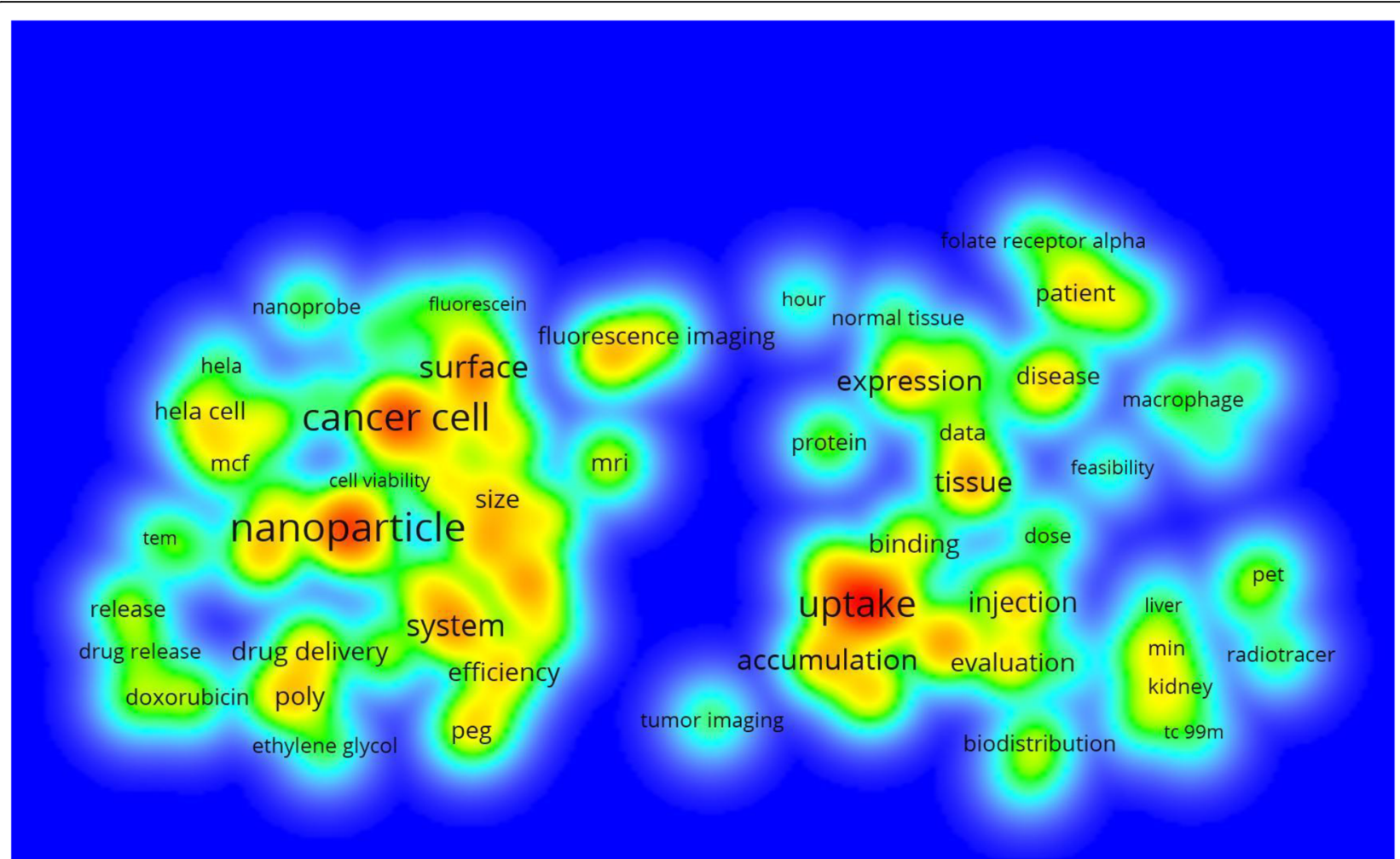

Fig. 8 Term density map of folate receptor research in cancer

\section{Acknowledgements}

Not applicable.

\section{Authors' contributions}

CD gathered and created and compiled datasets for bibliometric analysis. WH provided literature review and interpreted data. Both authors read and approved the final manuscript. The authors contributed equally to this work.

\section{Funding}

No funding was necessary for this study.

\section{Availability of data and materials}

The datasets used and/or analyzed during the current study are available from the corresponding author on reasonable request.

\section{Ethics approval and consent to participate}

Not Applicable.

\section{Consent for publication}

Not Applicable.

\section{Competing interests}

The authors declare that they have no competing interests.

Received: 20 May 2020 Accepted: 31 October 2020

Published online: 16 November 2020

\section{References}

1. Matherly LH, Goldman D. Membrane transport of folates. Vitam Horm. 2003; 66(66):403-56. https://doi.org/10.1016/s0083-6729(03)01012-4.

2. Leamon CP, Low PS. Delivery of macromolecules into living cells: a method that exploits folate receptor endocytosis. Proc Natl Acad Sci U S A. 1991:88: 5572-6. https://doi.org/10.1073/pnas.88.13.5572.

3. Antony AC. Folate receptors. Annu Rev Nutr. 1996;16:501-21. https://doi. org/10.1146/annurev.nu.16.070196.002441.
4. Rothberg KG, Ying YS, Kolhouse JF, Kamen BA, Anderson RGW. The glycophospholipid-linkes folate receptor internalizes folate without entering the clathrin-coated pit endocytic pathway. J Cell Biol. 1990;110:637-49. https://doi.org/10.1083/jcb.110.3.637.

5. Elnakat $H$, Ratnam M. Distribution, functionality and gene regulation of folate receptor isoforms: implications in targeted therapy. Adv Drug Deliv Rev. 2004;56:1067-84. https://doi.org/10.1016/j.addr.2004.01.001.

6. Sabharanjak S, Mayor S. Folate receptor endocytosis and trafficking. Adv Drug Deliv Rev. 2004;56:1099-109. https://doi.org/10.1016/j.addr.2004.01.010.

7. Low PS, Antony AC. Folate receptor-targeted drugs for cancer and inflammatory diseases - preface. Adv Drug Deliv Rev. 2004;56:1055-8. https://doi.org/10.1016/j.addr.2004.02.003.

8. Leamon CP, Low PS. Membrane folate-binding proteins are responsible for folate protein conjugate endocytosis into cultured-cells. Biochem J. 1993: 291:855-60. https://doi.org/10.1042/bj2910855

9. Paulos CM, Turk MJ, Breur GJ, Low PS. Folate receptor-mediated targeting of therapeutic and imaging agents to activated macrophages in rheumatoid arthritis. Adv Drug Deliv Rev. 2004;56:1205-17. https://doi.org/10.1016/j.addr. 2004.01.012.

10. Ke CY, Mathias CJ, Green MA. Folate-receptor-targeted radionuclide imaging agents. Adv Drug Deliv Rev. 2004;56:1143-60. https://doi.org/10.1016/j.addr. 2004.01.004.

11. Leamon CP, Reddy JA. Folate-targeted chemotherapy. Adv Drug Deliv Rev. 2004;56:1127-41. https://doi.org/10.1016/j.addr.2004.01.009.

12. Reddy JA, Low PS. Folate-mediated targeting of therapeutic and imaging agents to cancers. Crit Rev Ther Drug Carrier Syst. 1998;15:587-627.

13. Leamon CP, Low PS. Folate-mediated targeting: from diagnostics to drug and gene delivery. Drug Discov Today. 2001;6:44-51. https://doi.org/10. 1016/s1359-6446(00)01594-4.

14. Elwood PC. Molecular-cloning and characterization of the human folatebinding protein CDNA from placenta and malignant-tissue culture (KB) cells. J Biol Chem. 1989;264:14893-901.

15. Ratnam M, Marquardt H, Duhring JL, Freisheim JH. Homologous membran folate binding-proteins in human-placenta - cloning and sequence of a CDNA. Biochemistry. 1989;28:8249-54. https://doi.org/10.1021/bi00446a042. 
16. Shen F, Ross JF, Wang X, Ratnam M. Identification of a novel folate receptor, a truncated receptor, and receptor-type-beta in hematopoietic-cells - CDNA cloning, expression, immunoreactivity, and tissue-specificity. Biochemistry. 1994;33:1209-15. https://doi.org/10.1021/bi00171a021.

17. Spiegelstein O, Eudy JD, Finnell RH. Identification of two putative novel folate receptor genes in humans and mouse. Gene. 2000;258:117-25. https://doi.org/10.1016/s0378-1119(00)00418-2.

18. Bianchi E, Doe B, Goulding D, Wright GJ. Juno is the egg Izumo receptor and is essential for mammalian fertilization. Nature. 2014;508:483-7. https:// doi.org/10.1038/nature13203.

19. Ross JF, Chaudhuri PK, Ratnam M. Differential regulation of folate receptor isoforms in normal and malignant-tissues in-vivo and in established celllines - physiological and clinical implications. Cancer. 1994;73:2432-43. https://doi.org/10.1002/1097-0142(19940501)73:9<2432::aidcncr2820730929>3.0.co;2-s.

20. Weitman SD, et al. Cellular-localization of the folate receptor - potential role in drug toxicity and folate homeostasis. Cancer Res. 1992;52:6708-11.

21. Garinchesa P, et al. Trophoblast and ovarian-cancer antigen-LK-26 sensitivity and specificity in immunopathology and molecular-identification as a folate-binding protein. Am J Pathol. 1993;142:557-67.

22. Leamon CP, Low PS. Cytotoxicity of Momordin-folate conjugates in cultured human-cells. J Biol Chem. 1992;267:24966-71.

23. Atkinson SF, Bettinger T, Seymour LW, Behr JP, Ward CM. Conjugation of folate via gelonin carbohydrate residues retains ribosomal-inactivating properties of the toxin and permits targeting to folate receptor positive cells. J Biol Chem. 2001;276:27930-5. https://doi.org/10.1074/jbc. M102825200.

24. Steinberg G, Borch RF. Synthesis and evaluation of pteroic acidconjugated nitroheterocyclic phosphoramidates as folate receptortargeted alkylating agents. J Med Chem. 2001;44:69-73. https://doi.org/ 10.1021/jm000306g.

25. Ladino CA, Chari RVJ, Bourret LA, Kedersha NL, Goldmacher VS. Folatemaytansinoids: target-selective drugs of low molecular weight. Int J Cancer. 1997;73:859-64.

26. Wiener EC, Konda S, Shadron A, Brechbiel M, Gansow O. Targeting dendrimer-chelates to tumors and tumor cells expressing the high-affinity folate receptor. Investig Radiol. 1997;32:748-54. https://doi.org/10.1097/ 00004424-199712000-00005.

27. Reddy JA, Low PS. Enhanced folate receptor mediated gene therapy using a novel pH-sensitive lipid formulation. J Control Release. 2000;64:27-37.

28. Douglas JT, et al. Targeted gene delivery by tropism-modified adenoviral vectors. Nat Biotechnol. 1996;14:1574-8. https://doi.org/10.1038/nbt1196-1574.

29. Leamon CP, Weigl D, Hendren RW. Folate copolymer-mediated transfection of cultured cells. Bioconjug Chem. 1999;10:947-57. https://doi.org/10.1021/ bc990066n.

30. Lee RJ, Huang L. Folate-targeted, anionic liposome-entrapped polylysinecondensed DNA for tumor cell-specific gene transfer. J Biol Chem. 1996;271: 8481-7. https://doi.org/10.1074/jbc.271.14.8481.

31. Xu LA, Pirollo KF, Tang WH, Rait A, Chang EH. Transferrin-liposomemediated systemic 053 gene therapy in combination with radiation results in regression of human head and neck cancer xenografts. Hum Gene Ther. 1999;10:2941-52. https://doi.org/10.1089/10430349950016357.

32. Zhao XBB, Lee RJ. Tumor-selective targeted delivery of genes and antisense oligodeoxyribonucleotides via the folate receptor. Adv Drug Deliv Rev. 2004; 56:1193-204. https://doi.org/10.1016/j.addr.2004.01.005.

33. Nyanguile $\mathrm{O}$, et al. Synthesis of adenoviral targeting molecules by inteinmediated protein ligation. Gene Ther. 2003;10:1362-9. https://doi.org/10. 1038/sj.gt.3301989.

34. Reddy JA, Clapp DW, Low PS. Retargeting of viral vectors to the folate receptor endocytic pathway. J Control Release. 2001;74:77-82.

35. Citro G, Szczylik C, Ginobbi P, Zupi G, Calabretta B. Inhibition of leukemiacell proliferation by folic-acid polylysine-mediated introduction of C-MYB antisense oligodeoxynuvleotidesinto HL-60cells. Br J Cancer. 1994;69:463-7. https://doi.org/10.1038/bjc.1994.84.

36. Li S, Deshmukh HM, Huang L. Folate-mediated targeting of antisense oligodeoxynucleotides to ovarian cancer cells. Pharm Res. 1998;15:1540-5. https://doi.org/10.1023/a:1011946915209.

37. Liu JQ, Kolar C, Lawson TA, Gmeiner WH. Targeted drug delivery to chemoresistant cells: folic acid derivatization of FdUMP 10 enhances cytotoxicity toward 5-FU-resistant human colorectal tumor cells. J Org Chem. 2001;66:5655-63. https://doi.org/10.1021/jo005757n.
38. Wang S, Lee RJ, Cauchon G, Gorenstein DG, Low PS. Delivery of antisense oligodeoxyribonucleotides against the human epidermal growth-factor receptor into cultured $\mathrm{KB}$ cells with liposomes conjugated to folate via polyethylene-glycol. Proc Natl Acad Sci U S A. 1995;92:3318-22. https://doi. org/10.1073/pnas.92.8.3318.

39. Leopold LH, Shore SK, Newkirk TA, Reddy RMV, Reddy EP. Multiunit ribozyme-mediated cleavage of BCR-ABL messenger-RNA in myeloid leukemias. Blood. 1995;85:2162-70. https://doi.org/10.1182/blood.V85.8.2162. bloodjournal8582162.

40. Leopold LH, Shore SK, Reddy EP. Multi-unit anti-BCR-ABL ribozyme therapy in chronic myelogenous leukemia. Leuk Lymphoma. 1996;22:365-73. https://doi.org/10.3109/10428199609054774.

41. Guo WJ, Hinkle GH, Lee RJ. Tc-99m-HYNIC-folate: a novel receptor-based targeted radiopharmaceutical for tumor imaging. J Nucl Med. 1999:40:1563-9.

42. Wang S, Lee RJ, Mathias CJ, Green MA, Low PS. Synthesis, purification, and tumor cell uptake of Ga-67-deferoxamine-folate, a potential radiopharmaceutical for tumor imaging. Bioconjug Chem. 1996;7:56-62. https://doi.org/10.1021/bc9500709.

43. Leamon $C P$, et al. Synthesis and biological evaluation of EC20: a new folatederived, Tc-99m-based radiopharmaceutical. Bioconjug Chem. 2002;13: 1200-10. https://doi.org/10.1021/bc0200430.

44. Wang $\mathrm{S}$, et al. Design and synthesis of in-111 DTPA-folate for use as a tumor-targeted radiopharmaceutical. Bioconjug Chem. 1997:8:673-9. https:// doi.org/10.1021/bc9701297.

45. Mathias CJ, Wang S, Low PS, Waters DJ, Green MA. Receptor-mediated targeting of Ga-67-deferoxamine-folate to folate-receptor-positive human KB tumor xenografts. Nucl Med Biol. 1999;26:23-5. https://doi.org/10.1016/ s0969-8051(98)00076-6.

46. Pan $\mathrm{XQ}$, et al. Strategy for the treatment of acute myelogenous leukemia based on folate receptor beta-targeted liposomal doxorubicin combined with receptor induction using all-trans retinoic acid. Blood. 2002;100:594602. https://doi.org/10.1182/blood.V100.2.594.

47. Anderson KE, Eliot LA, Stevenson BR, Rogers JA. Formulation and evaluation of a folic acid receptor-targeted oral vancomycin liposomal dosage form. Pharm Res. 2001;18:316-22. https://doi.org/10.1023/a:1011002913601.

48. Gabizon A, Shmeeda H, Horowitz AT, Zalipsky S. Tumor cell targeting of liposome-entrapped drugs with phospholipid-anchored folic acid-PEG conjugates. Adv Drug Deliv Rev. 2004;56:1177-92. https://doi.org/10.1016/j. addr.2004.01.011.

49. Shukla S, et al. Synthesis and biological evaluation of folate receptor-targeted boronated PAMAM dendrimers as potential agents for neutron capture therapy. Bioconjug Chem. 2003;14:158-67. https:/doi.org/10.1021/bc025586o.

50. Sudimack JJ, et al. Folate receptor-mediated liposomal delivery of a lipophilic boron agent to tumor cells in vitro for neutron capture therapy. Pharm Res. 2002;19:1502-8. https://doi.org/10.1023/a: 1020408716807

51. Roy EJ, Gawlick U, Orr BA, Kranz DM. Folate-mediated targeting of T cells to tumors. Adv Drug Deliv Rev. 2004;56:1219-31. https://doi.org/10.1016/j.addr. 2004.01.006.

52. Lu YJ, Sega E, Leamon CP, Low PS. Folate receptor-targeted immunotherapy of cancer: mechanism and therapeutic potential. Adv Drug Deliv Rev. 2004;56:1161-76. https://doi.org/10.1016/j.addr.2004.01.009.

53. Lu YJ, Low PS. Folate targeting of haptens to cancer cell surfaces mediates immunotherapy of syngeneic murine tumors. Cancer Immunol Immunother. 2002;51:153-62. https://doi.org/10.1007/s00262-002-0266-6.

54. Lu JY, Hu GX, Wang XQ, Wu M, Liu J. Cloning and characterization of a novel gene EC97 associated with human esophageal squamous cell carcinoma. Int J Mol Med. 2003;11:243-7.

55. Cho BK, Roy EJ, Patrick TA, Kranz DM. Single-chain Fv/folate conjugates mediate efficient lysis of folate-receptor-positive tumor cells. Bioconjug Chem. 1997;8:338-46. https://doi.org/10.1021/bc9700244.

56. Kranz DM, Patrick TA, Brigle KE, Spinella MJ, Roy EJ. Conjugates of folate and anti-T-cell-receptor antibodies specifically target folate-receptor-positive tumor-cells for lysis. Proc Natl Acad Sci U S A. 1995;92:9057-61. https://doi. org/10.1073/pnas.92.20.9057.

57. Lu JY, Lowe DA, Kennedy MD, Low PS. Folate-targeted enzyme prodrug cancer therapy utilizing penicillin- $V$ amidase and a doxorubicin prodrug. J Drug Target. 1999;7:43-53. https://doi.org/10.3109/10611869909085491.

58. Quintana A, et al. Design and function of a dendrimer-based therapeutic nanodevice targeted to tumor cells through the folate receptor. Pharm Res. 2002;19:1310-6. https://doi.org/10.1023/a:1020398624602. 
59. Dube D, Francis M, Leroux JC, Winnik FM. Preparation and tumor cell uptake of poly(N-isopropylacrylamide) folate conjugates. Bioconjug Chem 2002;13:685-92. https://doi.org/10.1021/bc010084g.

60. Kono K, Liu MJ, Frechet JMJ. Design of dendritic macromolecules containing folate or methotrexate residues. Bioconjug Chem. 1999; 10BOC007607:1115-21. https://doi.org/10.1021/bc990082k.

61. Caliceti $P$, et al. Synthesis and physicochemical characterization of folatecyclodextrin bioconjugate for active drug delivery. Bioconjug Chem. 2003; 14:899-908. https://doi.org/10.1021/bc034080i.

62. Stevens PJ, Lee RJ. A folate receptor-targeted tinulsion formulation for paclitaxel. Anticancer Res. 2003;23:4927-31.

63. Kennedy MD, Jallad KN, Thompson DH, Ben-Amotz D, Low PS. Optical imaging of metastatic tumors using a folate-targeted fluorescent probe. J Biomed Opt. 2003;8:636-41. https://doi.org/10.1117/1.1609453.

64. Moon WK, et al. Enhanced tumor detection using a folate receptor-targeted near-infrared fluorochrome conjugate. Bioconjug Chem. 2003;14:539-45. https://doi.org/10.1021/bc0340114.

65. Sandoval RM, Kennedy MD, Low PS, Molitoris BA. Uptake and trafficking of fluorescent conjugates of folic acid in intact kidney determined using intravital two-photon microscopy. Am J Physiol Cell Physiol. 2004;287:C51726. https://doi.org/10.1152/ajpcell.00006.2004.

66. ClinicalTrials.gov. OTL38 Injection for intraoperative imaging of folate receptor positive lung nodules, 2019).

67. Andres A. Measuring Academic Research: How to undertake a Bibliometric Study. Oxford: Chandos Publishing; 2009.

68. Kotepui M, Wannaiampikul S, Chupeerach C, Duangmano S. A Bibliometric analysis of diets and breast Cancer research. Asian Pac J Cancer Prev. 2014; 15:7625-8. https://doi.org/10.7314/apjcp.2014.15.18.7625.

69. Analytics C. Web of Science: trust the difference. 2019. https://clarivate.com/ products/web-of-science/.

70. University, L. VOSviewer: visualizing scientific landscapes, <https://www. vosviewer.com/> (2019)

71. Viana J, et al. Remote Sensing in Human Health: A 10-Year Bibliometric Analysis. Remote Sensing. 2017:9. https://doi.org/10.3390/rs9121225.

72. Romero L, Portillo-Salido E. Trends in Sigma-1 Receptor Research: A 25-Year Bibliometric Analysis. Front Pharmacol. 2019;10. https://doi.org/10.3389/ fphar.2019.00564.

73. Olsen, D. \& Jã, Rgensen, J. T. S. Companion Diagnostics for Targeted Cancer Drugs â€" Clinical and Regulatory Aspects. Front Oncol 4, doi:https://doi. org/10.3389/fonc.2014.00105 (2014).

74. Fernández M, Javaid F, Chudasama V. Advances in targeting the folate receptor in the treatment/imaging of cancers. Chem Sci. 2018;9:790-810. https://doi.org/10.1039/c7sc04004k.

75. van Dam GM, et al. Intraoperative tumor-specific fluorescence imaging in ovarian cancer by folate receptor-a targeting: first in-human results. Nat Med. 2011;17:1315-9. https://doi.org/10.1038/nm.2472.

76. Blümel C, Schniedermann A. Studying review articles in scientometrics and beyond: a research agenda. Scientometrics. 2020;124:711-28. https://doi. org/10.1007/s11192-020-03431-7.

77. Nguyen TV, Ho-Le TP, Le UV. International collaboration in scientific research in Vietnam: an analysis of patterns and impact. Scientometrics. 2017;110:1035-51.

78. Knottnerus JA, Knottnerus BJ. Let's make the studies within systematic reviews count. Lancet. 2009;373:1605. https://doi.org/10.1016/s01406736(09)60906-5.

79. Ketcham CM, Crawford JM. The impact of review articles. Lab Investig. 2007; 87:1174-85. https://doi.org/10.1038/labinvest.3700688.

80. Amaniti A, et al. Pharmacologic and Non-Pharmacologic Interventions for HIV-Neuropathy Pain. A Systematic Review and a Meta-Analysis. Medicina. 2019;55:762. https://doi.org/10.3390/medicina55120762.

81. van der Pol CB, Mclnnes MDF, Petrcich W, Tunis AS, Hanna R. Is quality and completeness of reporting of systematic reviews and meta-analyses published in high impact radiology journals associated with citation rates? PLoS One. 2015;10:e0119892. https://doi.org/10.1371/journal.pone. 0119892.

82. Hutchins BI, Yuan X, Anderson JM, Santangelo GM. Relative citation ratio (RCR): a new metric that uses citation rates to measure influence at the article level. PLoS Biol. 2016;14:e1002541. https://doi.org/10.1371/journal. pbio.1002541.

83. Zyoud SEH, Waring WS, Al-Jabi SW, Sweileh WM. Global cocaine intoxication research trends during 1975-2015: a bibliometric analysis of
Web of Science publications. Substance Abuse Treat Prev Policy. 2017;12:66. https://doi.org/10.1186/s13011-017-0090-9.

84. Chen $H$, Yang $Y$, Yang $Y$, Jiang $W$, Zhou J. A bibliometric investigation of life cycle assessment research in the web of science databases. Int J Life Cycle Assess. 2014;19:1674-85. https://doi.org/10.1007/s11367-014-0777-3.

85. Mansoori P. 50 years of Iranian clinical, biomedical, and public health research: a bibliometric analysis of the web of science Core collection (1965-2014). J Glob Health. 2018;8:020701. https://doi.org/10.7189/jogh.08. 020701.

\section{Publisher's Note}

Springer Nature remains neutral with regard to jurisdictional claims in published maps and institutional affiliations.
Ready to submit your research? Choose BMC and benefit from:

- fast, convenient online submission

- thorough peer review by experienced researchers in your field

- rapid publication on acceptance

- support for research data, including large and complex data types

- gold Open Access which fosters wider collaboration and increased citations

- maximum visibility for your research: over $100 \mathrm{M}$ website views per year

At BMC, research is always in progress.

Learn more biomedcentral.com/submissions 